\title{
Pseudomonas syringae causing bacterial canker on apple trees in Brazil
}

\author{
Leonardo Araujo1,* (D), Yuliet Franco Cardoza² (D), Valmir Duarte² (D), Marcelo Gravina de Moraes ${ }^{3}$ (D) \\ 1. Empresa de Pesquisa Agropecuária e Extensão Rural de Santa Catarina - Departamento de Fitopatologia - São \\ Joaquim (SC), Brazil. \\ 2. Agronômica - Departamento de Fitopatologia - Laboratório de Diagnóstico Fitossanitário e Consultoria - Porto \\ Alegre (RS), Brazil. \\ 3. Universidade Federal do Rio Grande do Sul - Faculdade de Agronomia - Departamento de Fitossanidade - Porto \\ Alegre (RS), Brazil
}

\begin{abstract}
In March 2016, wilt and shoot blight were observed on five-year-old apple trees (Malus domestica) cultivar Maxi Gala in a commercial orchard in São Joaquim city, state of Santa Catarina, Brazil. Isolation on culture media, biolog, biochemical, LOPAT tests, and whole genome sequencing were performed. Koch's postulates were fulfilled on apple stems, leaves and fruits. The taxonomic position of a representative strain was determined by in silico DNA-DNA hybridization using the Genome-to-Genome Distance Calculator which showed 93.9\% similarity with Pseudomonas syringae. Results of biolog and biochemical tests did not match those expected for pv. papulans, morsprunorum or syringae. To our knowledge this is the first report of $P$. syringae causing bacterial canker in commercial apple orchards in Brazil.
\end{abstract}

Key words: bacterial canker, bacterial ooze, blister bark, blister spot, blossom blast, internal necrosis.

\author{
Received: \\ May 27, 2020 \\ Accepted: \\ Sep. 1, 2020 \\ Section Editor: \\ Fabrício de Ávila Rodrigues \\ *Corresponding author: \\ leonardoaraujo@epagri.sc.gov.br
}

Diseases of fruit trees caused by strains of the Pseudomonas syringae complex are of major concern in fruit producing areas worldwide, because they are exceedingly difficult to control, and result in economic losses (Kennelly et al. 2007; Young 2010; Gomila et al. 2017). Pseudomonas pathogens of fruit trees infect leaves, shoot tips, and fruits (Kennelly et al. 2007; Lee et al. 2015; Gašić et al. 2018). Infection of woody tissue is also important on fruit trees because cankers eventually girdle and kill branches, thereby resulting in loss of fruiting surface and tree death (Kennelly et al. 2007; Perminow et al. 2018). The P. syringae complex that infect fruit trees exhibit commonalities and differences in life cycles and the symptoms they incite, as well as in their biochemical, immunological, and molecular characteristics (Kerkoud et al. 2002; Kennelly et al. 2007; Young 2010; Gomila et al. 2017; Gašić et al. 2018). Pseudomonas syringae pv. syringae (Lee et al. 2015; Gašić et al. 2018; Perminow et al. 2018) and P. syringae pv. papulans (Kerkoud et al. 2002) are responsible for causing distinct disease symptoms on different tissues on apple trees.

In Brazil, during summer of 2016 (March), five-year-old apple trees cultivar Maxi Gala showing different symptoms such as wilt and shoot blight (Fig. 1a and b) were observed in a commercial apple orchard in São Joaquim city, state of Santa Catarina (28 $21^{\circ} 43.82^{\prime \prime S}$; 5002'57.04"O; altitude $1251 \mathrm{~m}$ ). Some shoots appeared to form a "shepherd's crook" symptom (Fig. 1b). Red-rust exudate in the form of droplets were observed on cankers (Fig. 1c) or extruding from lenticels (Fig. 1d). Symptomatic stems frequently showed internal necrotic tissues (Fig. 1e). Internal fragments with healthy and necrotic tissues exhibited strong bacterial cell exudation at the macro (Fig. 1f) and microscopic (Fig. 1h) level when placed in water according to Gonçalves et al. (2008). Three of 5.000 trees (aggregated pattern) were symptomatic and eradicated from the orchard after taking samples. The objective of the present study was to identify the pathogen responsible for causing the disease symptoms observed on apple trees in Brazil. 
Samples were collected from two apple trees for bacterial isolation. Then, internal fragments from symptomatic tissues were transferred to $1 \mathrm{~mL}$ of sterile distilled water. After $20 \mathrm{~min}$, a loopful of the macerate was streaked on King's B medium. Plates were incubated at $28 \pm 2{ }^{\circ} \mathrm{C}$ during $48 \mathrm{~h}$. Pure colonies of the bacterium appeared smooth, flat, with entire or slightly lobed margins, whitish-yellowish in color.

Indirect gram test with 3\% KOH (Suslow et al. 1982), oxidative/fermentative metabolism of glucose (Hugh and Leifson 1953) and LOPAT tests were performed, and three representative isolates were selected for diagnosis. Pure bacterial strains were streaked on Biolog Universal Growth agar plates and incubated at $28^{\circ} \mathrm{C}$ for $24 \mathrm{~h}$. The bacteria were swabbed from the
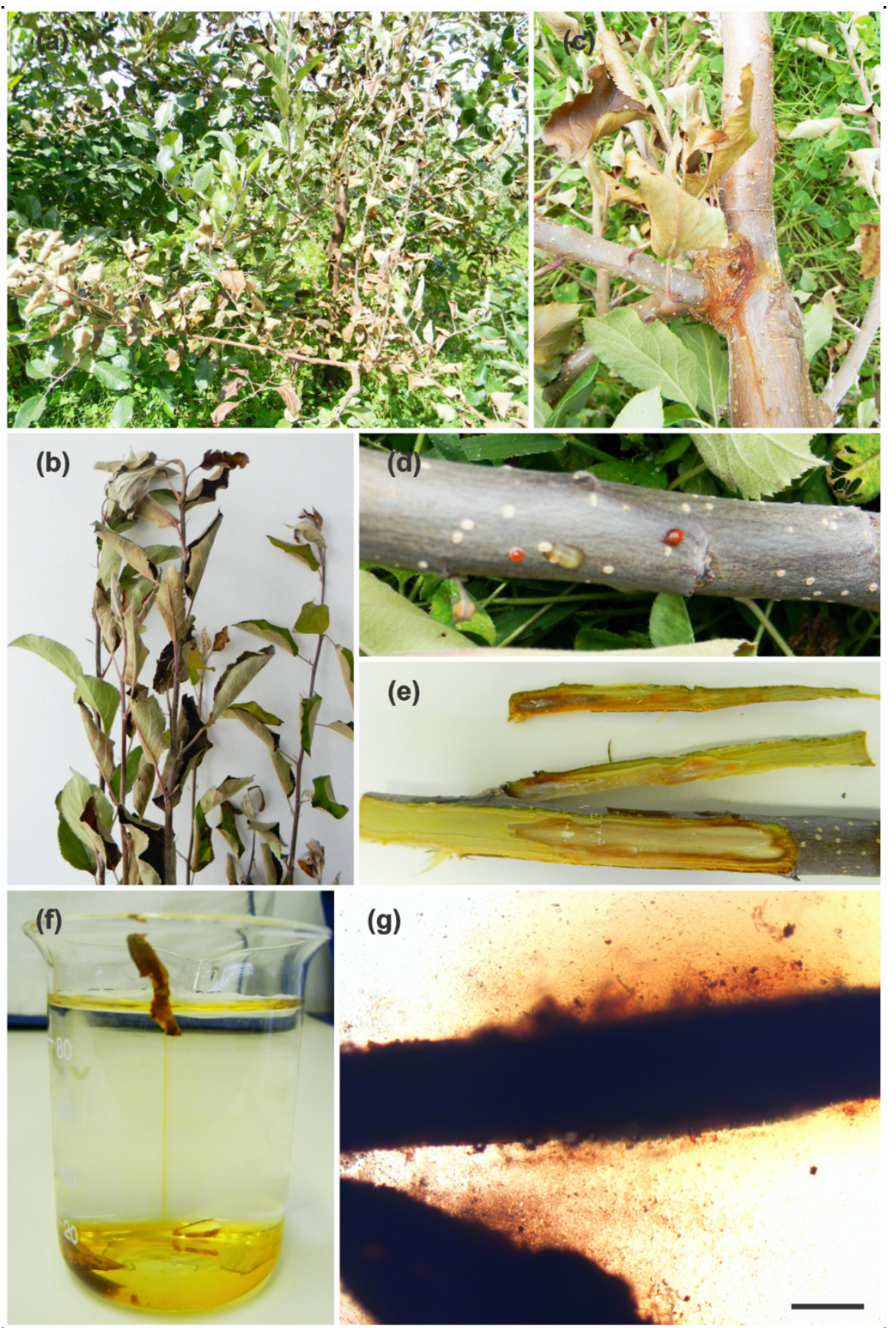

Figure 1. Symptoms of bacterial shoot ( $a, b, c$ and e) and signs of Pseudomonas syringae presence ( $d$, $f$ and $g$ ) on apple trees cultivar Maxi Gala. Wilt and blight in stem and shoots ( $a$ and $b$ ). Canker and lenticels with bacterial exudation ( $c$ and d). Internal necrotic tissues in longitudinal stem sections(e). Macro and microscopic exudation of bacterial ooze (f and g). Scale bar: $100 \mu \mathrm{m}$. 
surface of the agar plate, and suspended to a specified optical density $(\mathrm{OD} 600 \mathrm{~nm})$ in GN/GP inoculating fluid. One hundred and fifty microliters of a bacterial suspension $\left(10^{6} \mathrm{CFU} \cdot \mathrm{mL}^{-1}\right)$ was pipetted into each of the microplate. The microplate was incubated at $28^{\circ} \mathrm{C}$ for $24 \mathrm{~h}$, read visually and compared to the database of the Biolog GEN III MicroPlate ${ }^{\mathrm{TM}}$ system (Biolog ${ }^{\mathrm{TM}}$, Hayward, CA, USA).

Genomic DNA was extracted using the Wizard Genomic DNA Purification Kit (Promega Corp., Madison, WI) following the manufacturer's protocol and stored at $4{ }^{\circ} \mathrm{C}$. Bacterial genome sequencing (representative isolate IBSBF 3261) was performed using the Ion Torrent PGM (Life Technologies). The DNA library was constructed using 100 ng DNA by enzyme fragmentation and adaptor ligation with the Ion Xpress Plus fragment library kit (Life Technologies). Fragment size selection was performed using E-Gel SizeSelect 2\% (Invitrogen). After diluting the library at $100 \mathrm{pmol} \cdot \mathrm{L}^{-1}$, template preparation, emulsion polymerase chain reaction, and ion sphere particle (ISP) enrichment were performed using the Ion One Touch template kit (Life Technologies). The ISPs were loaded and sequenced on a 318 chip (Life Technologies). Genome assembly was generated by the Mimicking Intelligent Read Assembly (MIRA) assembler (Chevreux et al. 1999). The taxonomic positioning of the bacterial isolate was determined using in silico DNA-DNA hybridization methodology with the Genometo-Genome Distance Calculator (https://ggdc-test.dsmz.de/home.php) (Meier-Kolthoff et al. 2014).

To demonstrate the pathogenicity of the bacterium, ten detached apple leaves of cultivar Gala (Araujo and Stadnik 2011) were inoculated by the scissors-clipping method (Blair and McCouch 1997) with a bacterial suspension containing to $10^{6} \mathrm{CFU} / \mathrm{mL}$ (isolate IBSBF 3261). Three cuts on each detached apple leaf were made. After inoculation, the detached apple leaves were maintained in a growth chamber at $24^{\circ} \mathrm{C}, 12 \mathrm{~h}$ photoperiod and relative humidity of $90 \%$ for four days.

Bacterial isolate (IBSBF 3261) was inoculated on one-and-a-half-year-old apple plants cultivar Gala grafted on Marubakaido rootstock with the M.9 interstem. Inoculated plants were maintained in plastic pots containing $1 \mathrm{~kg}$ of substrate consisting of a mixture of soil, sand and manure in the proportion of 2:1:1. Two leaf petioles of the stem were detached with the help of a sterilized scalpel and then a drop $(50 \mu \mathrm{L})$ of bacterial cell suspension $\left(10^{6} \mathrm{CFU} / \mathrm{mL}\right)$ was placed on the wounds in the stem and covered with Parafilm (Koh et al. 2012). Inoculation was also performed following the methods of Araujo et al. (2014). A punch was used to remove bark disks from stem tissue (8-mm diameter and 2-mm height), and a plug removed from the middle portion of bacterial colonies was placed in the wound, which was then was carefully covered with a piece of moistened cotton and wrapped with Parafilm. Wilt and blight of the leaves, and internal necrosis in longitudinal stem sections of the four inoculated plants were evaluated at 10 and 30 days after inoculation (dai).

Immature apple fruits from the cultivars Braeburn, Fuji, Kinkas and Pink Lady were wounded (6.5-mm diameter and 2-mm depth) with a sterilized puncher at the fruit equator region. A drop $(50 \mu \mathrm{L})$ of bacterial cell suspension of a representative isolate $\left(10^{6} \mathrm{CFU} / \mathrm{mL}\right.$; IBSBF 3261) was placed in each wound (four wound/fruit). After inoculation, apple fruits were incubated at $24^{\circ} \mathrm{C}$ and $12 \mathrm{~h}$ photoperiod. The decay incidence was evaluated at four dai in four fruits per cultivar.

Pure greyish colonies producing green fluorescent pigment were obtained on King's B medium after samples processing. All purified isolates were Gram-negative, aerobic, negative for oxidase, induced hypersensitive reaction on tobacco plants, did not cause soft rot on potato slices and formed levan-positive colonies on nutrient sucrose agar (NSA) medium. Biolog GEN III MicroPlate ${ }^{\mathrm{TM}}$ system identified a representative isolate (IBSBF 3261) as P. syringae. Gelatin hydrolysis was negative. Furthermore, acid was produced from sucrose, but not from inositol and sorbitol. The results of these biochemical tests did not match those expected for pvs. papulans, morsprunorum or syringae, as reported in other works (Kerkoud et al. 2002; Lee et al. 2015; Gašić et al. 2018; Perminow et al. 2018). The precise taxonomic position of strains in the P. syringae species complex can be difficult at the pathovar level (Gomila et al. 2017). One isolate was deposited in the Coleção de Culturas de Fitobactérias IBSBF (Instituto Biológico, SP, Brazil) as P. syringae IBSBF 3261.

Genome assembly for selected isolate (IBSBF 3261) resulted in 484 contigs in total, N50 of 23,507 bp, L50 of 78 bp, and exhibited an average coverage of 15.0X. In silico DDH analysis was used for species demarcation. The recommended threshold value of species demarcation as per in silico DDH based method is 70\% (Meier-Kolthoff et al. 2014). This value was calculated to be $93.9 \%$ between the isolate IBSBF 3261 and P. syringae strain 31R1 and thus this method allowed allocation of the bacterial isolate to the P. syringae species. The genome sequence of isolate IBSBF 3261 was deposited in GenBank under accession No. NZ_QOSP00000000.1. 
Detached apple 'Gala' leaves showed intense necrosis at 4 dai in the areas where bacteria were inoculated by the scissors-clipping method (Fig. 2a). At 10 dai, different levels of wilting were observed in inoculated apple plants, in contrast to noninoculated ones (Fig. 2b). Some shoot from inoculated apple plants exhibited exudate in the form of droplets (Fig. 2c). Internal necrosis was observed proximal to the inoculation point in stem tissues obtained from inoculated plants (Fig. 2d). At 30 dai, strong wilting, without (Fig. 2e) or with (Fig. 2f and g) leaf blight were observed
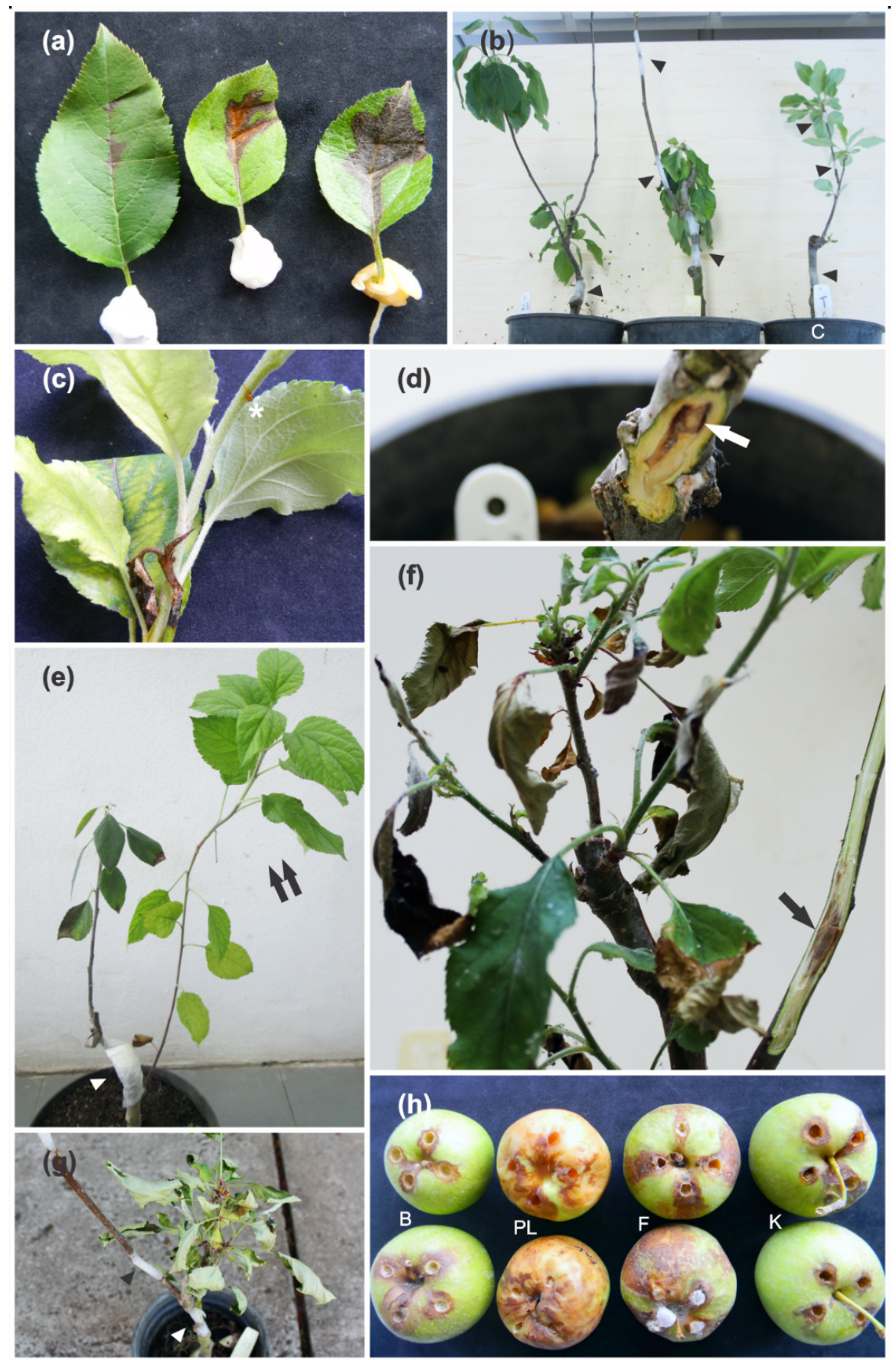

Figure 2. Disease symptoms ( $a, b, d, e, f, g$ and $h$ ) and bacterial signs (c) in apple leaves (a), plants (b to g) and fruit (h) at 4 ( $a$ and h), 10 (b to d) and 30 (e to g) days after inoculation (dai) with Pseudomonas syringae. Necrosis in leaves from Gala apple plants, where the bacterium was inoculated by scissors-clipping (a). The cultivar Gala used as the scion showed symptoms of wilting, whereas the rootstock Marubakaido was healthy with intense sprouting (double arrow) ( $b$ and e). Shoot from inoculated apple plants showing a bacterial exudation droplet (asterisk) (c). Inoculated areas (arrowheads) showed internal necrotic tissues (arrow) in longitudinal stem sections ( $d$ and f). Blight in apple plants $(f$ and $g$ ). Decay in inoculated immature apple fruits of cultivars Braeburn (B), Pink Lady (PL), Fuji (F) and Kinkas (K) (h). 
on inoculated apple plants. Sometimes, the dead plants and those with intense wilting had healthy rootstock with intense sprouting (Fig. 2e and g). Strong internal necrosis (Fig. 2f) was observed below the inoculation point underlying the wilt and blight symptoms. All fruits of every apple cultivar presented water-soaked lesions and rapid decay (Fig. 2h). The bacterium was recovered from inoculated tissues and its biochemical and physiological characteristics matched those of the inoculated strain.

In recent years, P. syringae affecting apple orchards have been reported in different countries. Lee et al. (2015) identified this bacterium as the causal agent of shoot blight of apple in 20 orchards in Korea. Perminow et al. (2018) described P. syringae causing blister bark in three orchards in southern Norway. Gašić et al. (2018) found the bacterium causing blossom blast symptoms on developing apple buds in commercial orchards in the United States. In South America, CABI (2019) reported that $P$. syringae pv. syringae can cause bacterial canker or blast on stone or pome fruits, but the authors did not include further details. In most reports, symptoms caused by $P$. syringae can occur following extended periods of cold, wet weather or after frost events (Mansvelt and Hattingh 1986, 1987; Cazorla et al. 1998; Rommel et al. 2010; Perminow et al. 2018).

An El Niño weather pattern of strong intensity was registered in the south of Brazil during spring 2015 and summer 2016 (Larini 2017). The mean temperature and total precipitation from September to February were higher than the historical mean, $2{ }^{\circ} \mathrm{C}$ and $450 \mathrm{~mm}$, respectively (Larini 2017). In South Africa, higher rainfall and lower temperatures during the leaf fall favored P. syringae infection, and the proportions of colonized apple buds increased sharply (Mansvelt and Hattingh 1986, 1987). In Southern Spain, P. syringae only incited bacterial symptoms on mango plants, when temperature was relatively low and the weather was rainy and wet (Cazorla et al. 1998). According to Kennelly et al. (2007), extreme weather conditions have often been associated with an increase of $P$. syringae populations and disease severity in the orchards. In Brazil, from December to February of 2008 , higher rainfall $(+240 \mathrm{~mm})$ and temperatures $\left(\geq 30^{\circ} \mathrm{C}\right)$ were associated with Pseudomonas spp. in European pear orchards (Rommel et al. 2010). The bacterial populations of Pseudomonas spp. caused the death of flowers in cultivars Packham's Triumph, Williams Bon Chretien and Abate Fetel (Rommel et al. 2010). Thus, in the present study, El Niño phenomenon could be associated with shoot blight and bacterial canker symptoms caused by $P$. syringae on apple trees in Brazil. Future studies, such as multilocus sequence analysis should be performed in order to identify the bacterium at the pathovar level. Although, the economic significance of this disease under the Brazilian conditions is uncertain, the presence of $P$. syringae in the country should be assessed as a potential threat, because its control is difficult and it causes serious economic losses.

To our knowledge, this is the first report of $P$. syringae causing shoot blight and bacterial canker symptoms on apple in commercial orchards in Brazil.

\section{ACKNOWLEDGMENTS}

The costs of bacterial genome sequencing were supported by Brazilian Association of Apple Producers (ABPM). The authors thank Arthur Oliveira Souza, Iran Souza Oliveira, Julie Zanin and Juliane Fernandes for their technical assistance.

\section{AUTHOR'S CONTRIBUTION:}

All authors contributed to the study conception and design. Identification of bacterial symptoms in apple orchard and Koch's postulates were performed by L. Araujo. Isolation on culture media, biochemical and LOPAT tests were performed by Y. F. Cardoza and V. Duarte. The taxonomic positioning of the strain using Genome-to-Genome Distance Calculator by in silico DNA-DNA was performed by M. G. Moraes. The first draft of the manuscript was written by L. Araujo and all authors commented on previous versions of the manuscript. All authors read and approved the final manuscript. 


\section{REFERENCES}

[CABI] Centre for Agriculture and Bioscience International. (2019). Invasive Species Compendium. Pseudomonas syringae pv. syringae (bacterial canker or blast (stone and pome fruits)) [Internet]. [Accessed Jul. 22, 2020]. Available at: https://www.cabi.org/isc/datasheet/45014

Araujo, L. and Stadnik, M. J. (2011). Processo infeccioso e atividade de enzimas em plântulas de macieira de genótipo resistente ou suscetível à mancha foliar de Glomerella causada por Colletotrichum gloeosporioides. Tropical Plant Pathology, 36, 241-248. https://doi. org/10.1590/S1982-56762011000400005

Araujo, L., Bispo, W. M. S., Cacique, I. S., Cruz, M. F. A. and Rodrigues, F. A. (2014). Histopathological aspects of mango resistance to the infection process of Ceratocystis fimbriata. Plant Pathology, 63, 1282-1295. https://doi.org/10.1111/ppa.12208

Blair, M. W. and McCouch, S. R. (1997). Microsatellite and sequence-tagged site markers diagnostic for the rice bacterial leaf blight resistance gene $x a-5$. Theoretical and Applied Genetics, 95, 174-184. https://doi.org/10.1007/s001220050545

Cazorla, F. M., Torés, J. A., Olalla, L., Pérez-García, A., Farré, J. M. and Vicente, A. (1998). Bacterial apical necrosis of mango in southern Spain: A disease caused by Pseudomonas syringae pv. syringae. Phytopathology, 88, 614-620. https://doi.org/10.1094/PHYTO.1998.88.7.614

Chevreux, B., Wetter, T. and Suhai, S. (1999). Genome sequence assembly using trace signals and additional sequence information. In German conference on bioinformatics (pp. 45-56). Hannover: GCB. [Accessed Jul. 22, 2020]. Available at: http://citeseerx.ist.psu.edu/ viewdoc/download?doi=10.1.1.23.7465\&rep=rep1\&type=pdf

Gašić, K., Pavlović, Ž., Santander, R. D., Meredith, C. and Aćimović, S. G. (2018). First report of Pseudomonas syringae pv. syringae associated with bacterial blossom blast on apple (Malus pumila) in USA. Plant Disease, 102, 1848. https://doi.org/10.1094/PDIS-01-18-0184-PDN

Gomila, M., Busquets, A., Mulet, M., García-Valdés, E. and Lalucat, J. (2017). Clarification of Taxonomic Status within the Pseudomonas syringae Species Group Based on a Phylogenomic Analysis. Frontiers in microbiology, 8, 2422. https://doi.org/10.3389/fmicb.2017.02422

Gonçalves, R. C., Lau, D., Oliveira, J. R., Maffia, L. A., Cascardo, J. C. M. and Alfenas, A. C. (2008). Etiology of bacterial leaf blight of eucalyptus in Brazil. Tropical Plant Pathology, 33, 180-188. https://doi.org/10.1590/S1982-56762008000300002

Hugh, R. and Leifson, E. (1953). The taxonomic significance of fermentative versus oxidative metabolism of carbohydrates by various Gram-negative bacteria. Journal of Bacteriology, 66, 24-26. https://doi.org/10.1128/JB.66.1.24-26.1953

Kennelly, M. M., Cazorla, F. M., Vicente, A., Ramos, C. and Sundin, G. W. (2007). Pseudomonas syringae diseases of fruit trees: Progress toward understanding and control. Plant Disease, 91, 4-17. https://doi.org/10.1094/PD-91-0004

Kerkoud, M., Manceau, C. and Paulin, J. P. (2002). Rapid diagnosis of Pseudomonas syringae pv. papulans, the causal agent of blister spot of apple, by polymerase chain reaction using specifically designed hrpL gene primers. Phytopathology, 92, 1077-1083. https://doi. org/10.1094/PHYTO.2002.92.10.1077

Koh, Y. J, Kim, G. H., Lee, Y. S., Sohn, S. H., Koh, H. S., Kwon, S., Heu, S. and Jung, J. S. (2012). Pectobacterium carotovorum subsp. actinidiae subsp. nov., a new bacterial pathogen causing canker-like symptoms in yellow kiwifruit, Actinidia chinensis. New Zealand Journal of Crop and Horticultural Science, 40, 269-279. https://doi.org/10.1080/01140671.2012.707129

Larini N. (2017). Análise das influências do fenômeno El Niño 2015-16 sobre a região sul do Brasil. (Thesis). Universidade Federal de Santa Catarina, Florianópolis, Brazil.

Lee, S., Cheon, W. and Jeon, Y. (2015). First report of bacterial shoot blight caused by Pseudomonas syringae pv. Syringae of apple (Malus pumila) in Korea. Plant Disease, 99, 1641. https://doi.org/10.1094/PDIS-11-14-1164-PDN

Mansvelt, E. L. and Hattingh, M. J. (1986). Bacterial blister bark and blight of fruit spurs of apple in South Africa caused by Pseudomonas syringae pv. syringae. Plant Disease, 70, 403-405. https://doi.org/10.1094/PD-70-403 
Mansvelt, E. L. and Hattingh, M. J. (1987). Pseudomonas syringae pv. syringae associated with apple and pear buds in South Africa. Plant Disease, 71, 789-792. https://doi.org/10.1094/PD-71-0789

Meier-Kolthoff, J. P., Klenk, H.-P. and Göker, M. (2014). Taxonomic use of DNA G+C content and DNA-DNA hybridization in the genomic age. International Journal of Systematic and Evolutionary Microbiology, 64, 352-356. https://doi.org/10.1099/ijs.0.056994-0

Perminow, J. I. S., Børve, J., Brurberg, M. B. and Stensvand, A. (2018). First report of Pseudomonas syringae pv. syringae causing bacterial blister bark on apple in Norway. Plant Disease, 102, 1653. https://doi.org/10.1094/PDIS-11-17-1712-PDN

Rommel, C. C., Valdebenito-Sanhueza, R. M. and Duarte, V. (2010). Detecção de bactérias associadas a gemas de pereiras europeias no Rio Grande do Sul. Tropical Plant Pathololgy, 35, 360-367. https://doi.org/10.1590/S1982-56762010000600004

Suslow, T. V., Schroth, M. N. and Isaka, M. (1982). Application of a rapid method for gram differentiation of plant pathogenic and saprophytic bacteria without staining. Phytopathology, 72, 917-918. https://doi.org/10.1094/phyto-72-917

Young, J. M. (2010). Taxonomy of Pseudomonas syringae. Journal of Plant Pathology, 92, S5-S14.

In the article Pseudomonas syringae causing bacterial canker on apple trees in Brazil with DOI: https://doi.org/10.1590/1678-4499.20200246, published in Bragantia vol.79 no.4 Campinas Oct./Dec. 2020:

In the footline where is read Bragantia, Campinas, v. 79, n. 4, p.467-473, 2020 should be read Bragantia, Campinas, v. 79, n. 4, p.592-598, 2020. 